\author{
Al-wardah: Jurnal Kajian Perempuan, Gender dan Agama \\ Volume: 12 Nomor : 1 \\ ISSN: 1907-2740, E-ISSN: 2613-9367 \\ DOI: $\mathrm{xxx} \mathrm{xxxx} \mathrm{xxxx}$
}

\title{
KONTEKSTUALISASI KARAKTER ANAK MELALUI PENDIDIKAN DAN PEMBELAJARAN
}

\author{
Amran Eku \\ IAIN Ternate,Indonesia \\ amraneku@gmail.com
}

\begin{abstract}
Abstrack
Character is a basic human potential in life, students have the potential to act, act, therefore every human being has a character, character, character and personality, which is automatically attached to an individual, formed from the results of internalizing various policies that are believed and used as a foundation for perspective, thinking, acting and acting. policy consists of a number of values, morals, and norms, such as honesty, dare to act, can be trusted and respectful of others. Character education needs to be developed in learning because these values apply universally, these values are sourced from religion, Pancasila and culture. The values of character education need to be elaborated so that contextual understanding is obtained, because it is useful as a limitation or benchmark for the achievement of the implementation of character education values in schools. The values of character education include religious, honest, disciplined and creative tolerance and democratic, national spirit, love of the motherland, respect, friendship, peace, and care for the environment, in the context of moral character, the character is understood in the form of moral values that leads students towards religious values which include husnudzhan, qanaah, ihlas, patience, istiqamah, istiqamahandpray.
\end{abstract}

Keywords: education, values and characte

\begin{abstract}
Abstrak
Karakter merupakan potensi dasar manusia dalam kehidupan, siswa memiliki potensi untuk berbuat, bertindak, oleh karena itu setiap manusia memiliki watak, tabiat, akhlak dan kepribadian, yang secara otomatis melekat pada diri individu, terbentuk dari hasil internalisasi berbagai kebijakan yang diyakini dan digunakan sebagai landasan untuk cara pandang, berpikir, bersikap, dan bertindak. kebijakan terdiri atas sejumlah nilai, moral, dan norma, seperti jujur, berani bertindak, dapat dipercaya dan hormat kepada orang lain. Pendidikan karakter perlu dikembangkan dalam pembelajaran oleh karena nilai ini berlaku universal, nilai-nilai ini bersumber dari agama, Pancasila dan budaya. Nilai-nilai pendidikan karakter perlu dijabarkan sehingga diperoleh pengertian secara kontekstual, karena berguna sebagai batasan atau tolak ukur ketercapaian pelaksanan nilai-nilai pendidikan karakter di sekolah. Adapun nilai-nilai pendidikan karakter meliputi Religius, jujur, disiplin dan kreatif toleransi dan demokratis, semangat kebangsaan, cinta Tanah air, Menghargai, bersahabat, cinta damai, dan peduli lingkungan, dalam konteks akhlakul karimah, karakter dipahami dalam bentuk nilai-nilai akhlak yang mengarah siswa terhadap nilai keagamaan yang meliputi husnudzhan, Qanaah, ihlas, sabar, istiqamah, istiqamah dan berdoa.
\end{abstract}

Kata Kunci: pendidikan, nilai dan karakter. 


\section{A. Pendahuluan}

Tujuan utama dari proses pendidikan dan pembelajaran di sekolah diantaranya adalah membentuk karakter siswa yang sempurna dalam kehidupan, sehingga siswa menjadi manusia yang sempurna, memililiki kepribadian yang sempurna dan dapat dijadikan sebagai pedoman hidup dan kehidupan baik untuk dirinya sendiri maupun sebagai anggota masyarakat, berbangsa dan bernegara.

Pada dasarnya setiap siswa adalah mahluk yang sempurna, karena mamiliki potensi untuk berpikir dan bertindak, mampu memilih dan memilah antara yang baik dan yang buruk, kesempurnaan siswa bisa dilihat dari struktur biologis dan psikologis, pertumbuhan fisik yang secara otomatis terbentuk secara sempurna, dan membedakan dengan mahluk - mahluk lain dibumi ini, aspek terpenting adalah psikologis (Jiwa) yang membuat manusia bisa berpikir, bertidak, dan dapat mengembangkan sikap kreatif dan inofatif, dapat berbudaya serta mengembangkan sikap dan prilaku dalam kehidupan.

Karakter merupakan potensi dasar manusia dalam kehidupan, siswa memiliki potensi untuk berbuat, bertindak, oleh karena itu setiap manusia memiliki watak, tabiat, akhlak dan kepribadian, yang secara otomatis melekat pada diri individu, terbentuk dari hasil internalisasi berbagai kebijakan yang diyakini dan digunakan sebagai landasan untuk cara pandang, berpikir, bersikap, dan bertindak. kebijakan terdiri atas sejumlah nilai, moral, dan norma, seperti jujur, berani bertindak, dapat dipercaya dan hormat kepada orang lain.

Nilai-nilai pendidikan karakter perlu dikembangkan di sekolah oleh karena nilai ini berlaku universal, karena dapat digunakan oleh seluruh siswa di Indonesia tanpa adanya diskriminasi terhadap pihak-pihak tertentu. Nilai-nilai ini bersimber dari agama, Pancasila dan budaya.Nilai-nilai pendidikan karakter perlu dijabarkan sehingga diperoleh pengertian secara kontekstual, karena berguna sebagai batasan atau tolak ukur ketercapaian pelaksanan nilai-nilai pendidikan karakter di sekolah. Adapun deskripsi nilai-nilai pendidikan karakter meliputi Religius (keagamaan), kepribadian (jujur, disiplin dan kreatif toleransi dan demokratis), kebangsaaan ( semangat kebangsaan, cinta Tanah air, dan sosial (Menghargai, bersahabat, cinta damai, dan peduli lingkungan) 
Guru memiliki peran penting sekaligus bertanggung jawab atas pendidikaan dan pembelajaran karakter di sekolah, karena guru bersentuhan langsung dalam proses pembelajaran di kelas, dapat membimbing dan mengarahkan siswa pada tujuan yang telah ditentukan, peran guru bisa bisa secara langsung melalui kurikulum pelajaran yang memiliki muatan karakter dapat dimplementasikan dalam proses belajar mengajar, dan juga bisa dilakukan di luar kelas dengan pembinaan maupun ceramah melalui kegiatatan intra kulikuler. Penerapan pendidikan karakter di sekolah dasar dilakukan pada ranah pembelajaran (kegiatan pembelajaran), pengembangan budaya sekolah dan pusat kegiatan belajar, intra kurikuler dan atau kegiatan ekstrakurikuler, dan kegiatan keseharian di rumah dan di masyarakat.Tujuan dari peneltian ini adalah untuk mengetahui perkembangan karakter anak di abngku sekolah. Kegunaan penelitian adalah Kegunaan praktis Hasil penelitian yang diperoleh dapat memberikan kontribusi kepada stake holder sekolah dan guru-guru yang mengintegralkan pendidikan karakter dalam setiap kegiatan maupun pembelajaran, salah satunya melalui kegiatan keagamaan. dan .keguanaan teoritis Memberi kontribusi ilmiah terhadap referensi pendidikan karakter yang dikembangkan melalui kegiatan keagamaan, nilai-nilai agama Islam yang bisa diterapkan pada kegiatan pembentukan karakter dan implikasinya terhadap siswa dalam penguatan karakter.

\section{B. Pembahasan}

\section{a) Kontekstualitas Karakter Siswa}

Karakter sebagai salah satu tujuan pendidikan Nasional harus dapat diimplementasikan dalam proses pendidikan dan pembelajaran, dimana siswa sebagai objek pembelajaran harus dapat didik dan dibentuk karakter sebagai manusia yang memiliki kepribadian yang sempurna. Oleh karena itu berturut-turut akan dijelaskan tentang peran guru dalam pendidikan karakter, tujuan dan manfaat karakter, ciri-ciri karakter dan kontekstualitas karakter dalam akhlakul karimah.

1. Peran dan tanggungjawab guru

Guru diberikan tugas dan tanggung jawab yang berat untuk mengembangkan potensi anak menjadi anak yang memiliki karakter yang mulia, sebab tanggung jawab guru adalah tanggung jawab professional tidak hanya sebatas dinding sekolah, tetapi juga di luar sekolah. Pembinaan yang harus di berikan tidak hanya secara kelompok 
(klasikal), tetapi juga secara individual masing-masing anak. Hal ini menuntut guru agar selalu memperhatikan sikap, tingkah laku, dan perbuatan anak didiknya, tidak hanya di lingkungan sekolah tetapi di luar sekolah.

Kast dan Rosenzweing (1985: 173-174), menjelaskan bahwa profesionalitas adalah proses yang akan mengakibatkan pekerjaanbergerak pada tingkat yang lebih tinggi atau lebih rendah salah satu unsurnya adalah terdapat keberlangsungan budaya organisasi, interaksi peran sosial yang disyaratkan oleh kelompok menghasilkan konfigurasi sosial yang unik pada profesi, yang disebut sebagai budaya profesional.

Pendapat Wolmer dan Mills yang dikutip Sardiman (1992: 134), mengemukakan bahwa pekerjaan dapat dikatakan sebagai suatu profesi, yaitu diakui dan didukung oleh masyarakat, memiliki persyaratan kerja yang sehat; dan memiliki hidup yang layak.

Pendapat lain tentang ciri profesional yang dikemukakan Westby dan Gibson menjelaskan ciri-ciri keprofesian di bidang pendidikan, diantaranya yaitu: memiliki bidang ilmu pengetahuan sebagai landasan dari sejumlah teknik dan prosedur, seperti psikologi, metodik dan sistematis. Dalam hubungan ini Hasibuan (1986: 41-42), menyatakan bahwa: Guru sebagai pemegang kunci (key person) sangat menentukan proses keberhasilan siswa. Yaitu menyampaikan informasi secara verbal maupun non verbal, dan memberi kesempatan kepada siswanya dalam mempelajari tugas yang ditentukan,

Zakiah Daradjat,(1996:32), menjadi guru harus memenuhi beberapa persyaratan yang terdiri dari Takwa kepada Allah Swt, berilmu pengetahuan, sehat jasmani dan rohani, serta berkelakukan baik . Menurutnya bahwa pendidikan diarahkan untuk mendekatkan diri kepa Allah Swt, sehingga anak akan tumbuh dan memiliki keyakinan yang sempurna, memiliki akhlak yang mulia, materi pelajaran diarahkan untuk memperkokoh keyakinan dan kepercayaannya, anak dapat melaksanakan semua perintah Allah dan Rasulnya dalam setiap langkah kehidupannya.

Menurut Syaiful Bahri (2000:34), mengatakan prinsipnya guru adalah orang yang memilik kemampuan dalam mencerdaskan anak melalui pendidikan dan pembelajaran, oleh karena itu seorang guru harus memiliki sifat yang baik dan benar, sehingga bisa menjadi cermin bagi guru lain, terutama bagi anak didiknya. Wens Tanlain menjelaskan bahwa seorang guru harus memiliki sifat yang baik dan benar dalam melaksanakan tugas dan tanggungjawabnya diantaranya adalah 1) Menerima dan 
mematuhi norma, nilai-nilai kemanusiaan; 2) Memikul tugas mendidik dengan bebas, berani,dan gembira, 3) takwa terhadap Tuhan Yang Maha Esa.

Guru memiliki tugas untuk membentuk jiwa dan watak anak didik, membentuk dan membangun kepribadian anak didik menjadi seorang yang memiliki kesempurnaan jasmani dan rohani. Guru bertugas mempersiapkan manusia siusila yang cakap yang dapat di harapkan membangun diri dan membangun bangsa dan negara. Roestiyah bahwa guru dalam proses pendidikan anak memiliki tugas yang berat tapi mulia untuk itu dia harus melakukan tugas diantaranya adalah Menyerahkan kebudayaan kepada anak didik, Membentuk kepribadian anak yang harmonis dan Menyiapkan anak menjadi warga negara yang baik

Menurut Sujtipto ( 1999:43), peranan yang diharapkan dari guru diantaranya seperti diuraikan sebagai berikut: Korektor, Motivator dan Pengelola Kelas. Guru sebagai korektor, yaitu guru harus bisa membedakan mana nilai yang baik dan mana nilai yang buruk. Kedua nilai yang berbeda ini harus betul-betul dipahami dalam kehidupan di masyarakat.Kedua nilai ini mungkin anak didik telah miliki dan mungkin pula telah mempengruhinya sebelum anak didik masuk sekolah. Sebagai motivator, guru hendaknya dapat mendorong anak didik agar bergairah dan aktif belajar. Dalam upaya memberikan motivasi, guru dapat menganalisis apa yang melatar belakangi anak didik malas belajar dan menurun prestasinya di sekolah. setiap saat guru harus bertindak sebagai motivator, karena dalam interaksi edukatif tidak mustahil ada di antara anak didik yang malas belajar. Sehingga muncul Inisiator, dalam perananya sebagai inisiator, guru harus dapat menjadi pencertus ide-ide kemajuan dalam pendidikan dan pengajaran. proses interaksi edukatif yang ada sekarang harus diperbaiki sesuai perkembangan ilmu pengetahuan dan teknologi dibidang pendidikan. Guru sebagai pengelola kelas, yaitu sebagai pengelola kelas, guru hendaknya dapat mengelola kelas dengan baik, karena kelas adalah tempat berhimpun semua anak didik dan guru dalam rangka menerima bahan pelajaran. Kelas yang dikelola dengan baik akan menunjang jalannya interaksi edukatif. Sebaliknya, kelas yang tidak dikelola dengan baik akan menghambat kegiatan pengajaran.

Syamsul Bahri Jamrah mengatakan seorang guru juga harus memiliki kode etik diantaranya sebagaimana di uraikan sebagai berikut : 1) Guru berbakti membimbing anak didik seutuhnya untuk membentuk manusia pembangunan, 2) Guru memiliki 


\section{Kontekstualisasi Karakter Anak...}

kejujuran profesional dalam menerapkan kurikulum sesuai kebutuhan anak didik masing-masing, 3) Guru mengadakan komunikasi, terutama dalam memperoleh informasi tentang anak didik, tetapi menghidarkan diri dari segala bentuk penyalahgunaan. 4) Guru melaksanakan segala ketentuan yang merupakan kebijaksanaan pemerintah dalam bidang pendidikan. Keberhasilan guru dalam melaksanakan perannya dalam bidang pendidikan sebagian besar terletak pada kemampuannya melaksanakan berbagai peran yang besifat khusus dalam situasi belajar mengajar.

\section{Tekstual karakter.}

Karakter diartikan sebagai watak, tabiat, akhlak, atau kepribadian seseorang yang terbentuk dari hasil internalisasi berbagai kebijakan yang diyakini dan digunakan sebagai landasan untuk cara pandang, berpikir, bersikap, dan bertindak. kebijakan terdiri atas sejumlah nilai, moral, dan norma, seperti jujur, berani bertindak, dapat dipercaya dan hormat kepada orang lain. Bila dua pengertian tadi digabung, akan menjadi pendidikan yang mengkarakterkan siswa. Lebih lanjut, pengertian pendidikan karakter adalah pendidikan yang mengembangkan nilai-nilai budaya dan karakter bangsa pada diri siswa sehingga mereka memiliki nilai dan karakter sebagai karakter, menerapkan nilai-nilai tersebut dalam kehidupan dirinya, sebagai anggota masyarakat, dan warga negara yang religius, nasionalis, produktif dan kreatif.

Untuk dapat melaksanakan pendidikan karakter, perlu diketahui fungsi dan tujuan pendidikan karakter adalah :

a. Pengembangan: pengembangan potensi siswa untuk menjadi pribadi berperilaku baik; ini bagi siswa yang telah memiliki sikap dan perilaku yang mencerminkan budaya dan karakter bangsa;

b. Perbaikan: memperkuat kiprah pendidikan nasional untuk bertanggung jawab dalam pengembangna potensi siswa yang lebih bermartabat; dan

c. Penyaring: untuk menyaring budaya bangsa sendiri dan budaya bangsa lain yang tidak sesuai dengan nilai-nilai budaya dan karakter bangsa yang bermartabat.

Sedangkan tujuan pendidikan karakter adalah:

a. Mengembangkan potensi Qalbu/ nurani/ efektif siswa sebagai manusia dan warga negara yang memiliki nilai-nilai budaya dan karakter bangsa; 
b. Mengembangkan kebiasaan dan perilaku siswa yang terpuji dan sejalan dengan nilai-nilai universal dan tradisi budaya bangsa yang religius;

c. Menanamkan jiwa kepemimpinan dan tanggung jawab siswa sebagai generasi penerus bangsa;

d. Mengembangkan kemampuan siswa menjadi manusia yang mandiri, kreatif, berwawasan kebangsaan; dan

e. Mengembangkan lingkungan kehidupan sekolah sebagai lingkungan belajar yang aman, jujur, penuh kreativitas dan persahabatan, serta dengan rasa kebangsaan yang tinggi dan penuh kekuatan (dignity).

3. Kontektualitas karakter.

Nilai-nilai pendidikan karakter perlu dikembangkan di sekolah. Nilai ini berlaku universal, karena dapat digunakan oleh seluruh siswa di Indonesia tanpa adanya diskriminasi terhadap pihak-pihak tertentu.Nilai-nilai ini bersimber dari agama, Pancasila dan budaya Adapun penjelasannya adalah sebagai berikut.

1. Agama: Masyarakat Indonesia adalah masyarakat beragama. Oleh karena itu, kehidupan individu, masyarakat, dan bangsa selalu didasari pada ajaran agama dan kepercayaannya.Secara politisi, kehidupan kenegaraan pun didasari pada nilai-nilai yang berasal dari agama. Atas dasar pertimbangan itu, maka nilai-nilai pendidikan budaya dan karakter bangsa harus didasarkan pada nilai-nilai dan kaidah yang berasal dari agama.

2. Pancasila: Negara kesatuan Republik Indonesia ditegakkan atas prinsip-prinsip kehidupan Kebangsaan dan kenegaraan yang disebut pancasila. Pancasila terdapat pada pembukaan UUD 1945 dan dijabarkan lebih lanjut dalam pasalpasal yang terdapat dalam UUD 1945.Artinya, nilai-nilai yang terkandung dalam Pancasila menjadi nilai-nilai yang mengatur kehidupan politik, hukum, ekonomi, kemasyarakatan, budaya dan seni.

3. Pendidikan budaya dan karakter bangsa bertujuan mempersiapkan siswa menjadi warga negara yang lebih baik, yaitu warga negara yang memiliki kemampuan, kemauan, dan menerapkan nilai-nilai Pancasila dalam kehidupannya sebagai warga negara 
Kontekstualiatas nilai-nilai pendidikan karakter adalah sebagai berikut: Religius, jujur, toleransi, disiplin, kerja Keras, kreatif, mandiri, demokratis, rasa ingin tahu, semangat kebangsaan, cinta Tanah air, menghargai prestasi, bersahabat, cinta damai, gemar membaca, peduli lingkungan, peduli sosial, tanggung Jawab.

Aspek-aspek tersebut diatas akan dapat dijelaskan agar dapat dipahami keterkaitan antara satu aspek dengan aspek lain sebagai satu kesatuan yang utuh dalam kehidupan.

Religius adalah Karakter yang dibangun atas sikap dan perilaku yang patuh dalam melaksanakan ajaran agama yang dianutnya, toleran terhadap pelaksanaan ibadah agama lain, dan hidup rukun dengan pemeluk agama lain. Terbentuk prilaku jujur yaitu perilaku yang didasarkan pada upaya menjadikan dirinya sebagai orang yang selalu dapat dipercaya dalam perkataan, tindakan, dan pekerjaan, mmampu bertoleransi dengan sikap dan tindakan yang menghargai perbedaan agama, suku, etnis, pendapat, sikap dan tindakan orang lain yang berbeda dari dirinya.

Aspek pembentukan disiplin sebagai tindakan yang mennunjukkan perilaku tertib dan patuh pada berbagai ketentuan dan peraturan, sehingga melahirkan kerja keras yaitu perilaku yang menunjukkan upaya sungguh-sungguh dalam mengatasi berbagai hambatan belajar dan tugas, serta menyelesaikan tugas dengan sebaik-baiknya. Sehingga memunculkan sikap kreatif yaitu berpikir dan melakukan sesuatu untuk menghasilkan cara atau hasil baru dari sesuatu yang telah dimiliki, Bisa hidup mandiriyaitu sikap dan perilaku yang tidak mudah tergantung pada orang lain dalam menyelesaikan tugas-tugas.

Karakter demokratis sebagai cara berfikir, bersikap, dan bertindak yang menilai sama hak dan kewajiban dirinya dan orang lain. Sehingga anak memiliki rasa Ingin ahu yaitu sikap dan tindakan yang selalu berupaya untuk mengetahui lebih mendalam dan meluas dari sesuatu yang di pelajarinya, dilihat, dan didengar, mengarah pada semangat kebangsaan dengan cara berpakir, bertindak, dan berwawasan yang menempatkan kepentingan bangsa dan negara di atas kepentingan diri dan kelomopknya. yang dapat mencintai tanah air yaitu cari berfikir, bersikap, dan berbuat yang menunjukkan kesetiaan, kepeduliaan, dan penghargaan yang tunggi terahadap bahasa, lingkungan fisik, sosial, budaya, ekonomi, dan politik bangsa. 
Selanjutnya menghargai prestasi yaitu sikap dan tindakan yang mendorong dirinya untuk menghasilkan sesuatu yang berguna bagi masyarakat, dan mengakui, serta menghormati keberhasilan orang lain, bersifat bersahabat dengan tindakan yang memperlihatkan rasa senang berbicara, Komunikatof, bergaul, dan bekerja sama dengan orang lain, lahirnya cinta damai, Sikap, perkataan, dan tindakan yang menyebabkan orang lain merasa senang dan aman atas kehadiran dirinya.

Menurut Hapsari( 2016 :296), anak yang berperilaku prososial akan lebih sering menerima perilaku prososial dari orang lain dan anak yang mengembangkan perilaku prososialnya sejak dini cenderung untuk memiliki banyak teman dan lebih disukai . Beberapa anak pada usia 5-6 tahun sudah terbiasa menawarkan bantuan kepada temantemannya yang lain, bersikap baik kepada semua orang, dan mampu untuk menerima perbedaan yang ada pada setiap anak. Anak yang sudah melakukan kebaikan kepada orang lain, maka orang lain juga akan melakukan kebaikan pula kepada anak tersebut.

Menurut William dalam Dayakshini (2009:175), membatasi perilaku prososial secara lebih rinci sebagai perilaku yang memiliki intensi untuk mengubah keadaan fisik atau psikologis penerima bantuan dari kurang baik menjadi lebih baik, dalam arti secara material maupun psikologis. Dalam hal ini dapat dikatakan bahwa perilaku prososial bertujuan untuk membantu meningkatkan well being orang lain. Sehingga dapat dipahami bahwa perilaku prososial adalah perilaku menguntungkan yang akan diterima oleh orang yang ditolong tetapi belum tentu menguntungkan bagi orang yang sudah menolong

Perilaku prososial merupakan salah satu bentuk perilaku yang muncul dalam kontak sosial. Watson, mendefinisikan perilaku prososial sebagai suatu tindakan yang memiliki konsekuensi positif bagi orang, tindakan menolong sepenuhnya yang dimotivasi oleh kepentingan sendiri tanpa mengharapkan sesuatu untuk dirinya. Tindakan prososial menuntut pengorbanan tinggi dari pelaku dan bersifat sukarela atau lebih ditunjukkan untuk menguntungkan orang lain daripada untuk mendapatkan imbalan materi yang maju harus memiliki sifat gemar membaca kebiasaan menyediakan waktu untuk membaca berbagai bacaan yang memberikan kebijakan bagi dirinya, membentuk sikap peduli lingkungan sebagai sikap dan tindakan yang selalu berupaya mencegah kerusakan pada lingkungan alam di sekitarnya, dan mengembangkan upayaupaya untuk memperbaiki kerusakan alam yang sudah terjadi. Dan peduli Sosial yaitu 


\section{Kontekstualisasi Karakter Anak...}

sikap dan tindakan yang selalu ingin memberi bantuan pada orang lain dan masyarakat yang membutuhkan dan karakter tanggung jawab yaitu sikap dan perilaku seseorang untuk melaksanakan tugas dan kewajibannya, yang seharusnya dia lakukan, terhadap diri sendiri, masyarakat, lingkungan (alam, sosial dan budaya), negara dan tuhan Yang Maha Esa .Pendidikan karakter meliputi dua aspek yang dimiliki manusia, yaitu aspek ke dalam dan aspek ke luar. Aspek ke dalam atau aspek potensi meliputi aspek kongnitif (Olah pikir), afektif (Olah hati), dan psikomotor (Olah rasa). Aspek ke luar yaitu aspek manusia dalam konteks sosiokultur dalam interaksinya dengan orang lain yang meliputi interaksi dalam keluarga, sekolah, dan masyarakat. Masing-masing aspek memilikiruang yang berisi nilai-nilai pendidikan karakter.

Penjelasan ruang lingkup pendidikan karakter adalah sebagai berikut: Olah pikir : Cerdas, kritis, kreatif, inovatif, ingin tahu, berpikir terbuka, produktif, berorientasi ipteks, dan reflektif. Olah hati : Beriman dan bertakwa, jujur, amanah, adil, bertanggung jawab, berempati, berani mengambil resiko, pantang menyerah, rela berkorban, dan berjiwa patriotik. Olah Rasa/Karsa : Ramah, saling menghargai, toleran, peduli, suka menolong, gotong royong, nasionalis, kosmopolit, mengutamakan kepentingan umum, banga menggunakan bahasa dan produk Indonesia, dinamis, kerja keras, dan beretos kerja karakter dalam Akhlakul Karimah. Akhlak terpuji adalah suatu aturan atau norma yang mengatur hubungan antar sesama manusia dengan tuhan dan alam semesta. Menurut M. Athiyah (1984:22), membagi macam-macam akhlakul karimah sebagai berikut:

a. Khusnudzhan kepada Allah

Khusnudzhan kepada Allah adalah kita memiliki keyakinan yang kuat bahwa Allah SWT yang Maha Pengasih lagi Maha Penyayang senantiasa berbuat dan menentukan yang terbaik untuk kehidupan manusia.

b. Qana'ah

Qana'ah dalam kacamata ilmu akhlak memiliki arti menerima segala anugerah yang diberikan Allah SWT serta bersabar atas ketentuannya besar dan tidak meninggalkan usaha dan ikhtiar lahiriyah. Orang mempunyai sifat qana'ah akan memiliki pendirian apa yang diperoleh atau apa yang ada pada dirinya adalah sesuai dengan Qadar ketentuan Allah SWT . 
c.. Ikhlas

Ikhlas adalah mengerjakan sesuatu perbuatan yang baik tanpa pamrih kecuali hanya karena Allah dan mengharapkan ridha-Nya. Beramal dengan ikhlas akan menjadikan seseorang bekerja dengan jujur, disiplin dan tanggung jawab, serta sanggup berkorban dalam melaksanakan tugas pekerjaan tersebut.

d. Sabar

Sabar artinya tahan uji, tahan menderita, menerima apa yang diberikan Allah baik yang berupa nikmat maupun berupa penderitaan. Orang yang sabar adalah orang yang memiliki keteguhan dan ketabahan hati dalam usaha mencapai citacita.

e. Istiqomah

Dalam bahasa Indonesia padanan kata istiqomah adalah kata "taat asas", yakni selalu taat dan setia kepada asas suatu keyakinan oleh sebab itulah orang yang istiqomah dikatakan juga sebagai orang yang taat asas. Orang yang berlaku istiqomah disebut juga orang yang mempunyai resiko yang tidak kecil seperti mendapat celaan.

f. Tasammuh

Dalam bahasa Indonesia, kata tasammuh dapat diartikan dengan tenggang rasa, lapang dada atau toleransi. Oleh karena itu orang yang bersifat tasammuh berarti memiliki kelapangan dada, menghormati orang yang berpendapat atau berpendirian lain, tidak mau mengganggu kebebasan berfikir dan orang berkeyakinan lain.

g. Ikhtiar (Kerja Keras)

Untuk mempertahankan hidup dan kehidupan, manusia dituntut untuk berjuang baik secara perorangan (individu) maupun secara kelompok (kolektif).Tuntutan tersebut berdasarkan fitrah (naluri) kemanusiaan yang tumbuh karena adanya hidayah dari Allah sesuai asas penciptaan-Nya.

h. Berdoa

Yaitu memohon kepada Allah, agar segala yang telah kita lakukan ada dalam ridha dan diqobulkan oleh Allah SWT. 


\section{Simpulan}

Untuk memudahkan pemahaman dari uraian tersebut diatas dapat ditarik beberapa kesimpulan sebagai berikut.

Guru memiliki peran penting dalam proses pembentukan karakter siswa, oleh karena guru bersentuhan langsung dengan siswa dalam proses pendidikan dan pembelajaran di sekolah. Guru memiliki tugas untuk membentuk jiwa dan watak anak didik, membentuk dan membangun kepribadian anak didik menjadi seorang yang memiliki kesempurnaan jasmani dan rohani. Guru bertugas mempersiapkan manusia siusila yang cakap yang dapat di harapkan membangun diri dan membangun bangsa dan negara.

Pendidikan karakter perlu dikembangkan dalam pembelajaran oleh karena nilai ini berlaku universal, nilai-nilai ini bersumber dari agama, Pancasila dan budaya. Nilainilai pendidikan karakter perlu dijabarkan sehingga diperoleh pengertian secara kontekstual, karena berguna sebagai batasan atau tolak ukur ketercapaian pelaksanan nilai-nilai pendidikan karakter di sekolah. Adapun nilai-nilai pendidikan karakter meliputi Religius (keagamaan), kepribadian (jujur, disiplin dan kreatif toleransi dan demokratis), kebangsaaan ( semangat kebangsaan, cinta Tanah air, dan sosial (Menghargai , bersahabat, cinta damai, dan peduli lingkungan), dalam konteks akhlakul karimah, karakter dipahami dalam bentuk nilai-nilai akhlak yang mengarah siswa terhadap nilai keagamaan yang meliputi husnudzhan, Qanaah, ihlas, sabar, istiqamah, istiqamah dan berdoa.

\section{Daftar Pustaka}

E. Mulyasa. (2007).Profesionalisme guru..Jakarta: Pt. Bulan Bintang.

Dayakisni dan Hudaniah. (2009). Psikologi Sosial. Malang: UMM Press.

Hapsari,(2016), Iriani. Psikologi Perkembangan Anak. Jakarta: Indeks.

J.J. Hasibuan.( 1986.) Proses Belajar Mengajar. Bandung: Remaja Karya, h. 41-42.

Fremont E. Kast and James E. Rosenzweing,(1985). Organization and Management; A System and Contingency Approach (USA: McGraw Hill Book Company, 1985), pp. 173 - 174.

M. Athiyah Al-Abrasih,(1984). Dasar Dasar pendidikan Islam. Jakarta : Bulan Bintang, 
Ngalim Purwanto,(2002). Ilmu Pendidikan teori dan Praktis. (Cet. I. Bandung : Remaja Karya,)

Nuryani Mira N, (2015) "Pendidikan Karakter Dalam Pembelajaran IPA Kelas V di SD Islam Al Hikmah Selokerto Sempor Kebumen” Skripsi, IAIN Purwokerto

Ny Roetiyah N.K,(2004) Masalah-Masalah Ilmu Keguruan, (Cet, III. Jakarta: Bina Aksara,

Sri Anitah Wirajawan dan Nordihadi,(1989). Strategi Belajar Mengajar,(Cet, II. Jakarta: Unifersitas Terbuka

Soejipto dan Raflis Kosasi.(1999).Profesi Guru, Cet, I. Jakarta: Rinaka Cipta

Sardiman A.M.(1992). Interaksi dan Motifasi Belajar Mengajar. (Cet. IV. Jakarta: Rajawali,). H. 134

Syaiful Bahri Djamarah.(2000). Guru Dan Anak Didik Dalam Interaktif Edukatif, (Cet.Pertama. Jakarta: Reneka Cipta,)

S.C.U. Munandar,(1999). Mengembangkan bakat dan kreatif anak sekolah, petunjuk bagi guru dan orang tua. (Jakarta: PT. Gramedia )

Tim penyusun.Bahan Pelatihan Penguatan Metodologi Pembelajaran Berdasarkan Nilai-Nilai Budaya Untuk Membentuk daya Saing Dan karakter Bangsa (2010): Pengembangan Pendidikan Budaya dan Karakter bangsa. Jakarta : Pusat Kurikulum Badan Penelitian Dan Pengembangan Kementrian Pendidikan Nasional.

Tim Penyusun. Pedoman Pelaksanaan Pendidikan Karakter: berdasarkan pengalaman di satuan pendidikan rintian. Jakarat : Puskurbuk Badan Penelitian Dan Pengembangan Kementrian Pendidikan Nasional.2011

Tim Penyusun. Rencana Aksi Nasional (RAN) Pendidikan Karakter Kementerian Pendidikan Nasional (2010-2014 )(Online), http://pendikar.dikti.go.id/gdp/wpcontent/uploads/Naskah-Ran-Kemendiknas-Rev-2 pdf, diakses 1 Maret 2014

Wahyono, Agus (2013), "Upaya Guru Dalam Meningkatkan Prestasi Belajar Mata Pelajaran PKN Kelas III MI Isiqomah Sambas Purbalingga" Skripsi, IAIN Purwokerto,

Wina sanjaya,(2006).Pembelajaran implementasi kurikulum berbasis kompetensi.Jakarta, Kencana

Zakiyah Darajat, Dkk .Metodologi Pengajaran Agama Islam, ( Sinar Grafika) 